BRONZE AGE SUBSISTENCE STRATEGIES IN THE SOUTHEASTERN CARPATHIAN BEND AREA, ROMANIA: RESULTS FROM STABLE ISOTOPE

ANALYSES

\title{
Journal of Archaeological Science: Reports
}

\author{
17 (2018) 510-519
}

${ }^{a}$ School of History, Classics, and Archaeology, University of Edinburgh, Old Medical School, Teviot Place, Edinburgh EH8 9AG, UK

b ‘Francisc I. Rainer' Institute of Anthropology, Romanian Academy, Bucharest, Romania

${ }^{\mathrm{c}}$ NERC Isotope Geosciences Laboratory, British Geological Survey, Keyworth, Nottingham NG12 5GG, UK

${ }^{1}$ Present address: Archaeological Research Collection, Tallinn University, Rüütli 10, 10130, Tallinn, Estonia

Corresponding author: Ülle Aguraiuja

Tel: +37255518469

Email address: ulle.aguraiuja@gmail.com 
Bronze Age subsistence strategies in the southeastern Carpathian Bend area, Romania: results from stable isotope analyses

Ülle Aguraiuja, Mihai Constantinescu, Angela Lamb, Clive Bonsall

\section{Abstract}

Here we report the results of stable carbon and nitrogen isotope analyses of human and faunal remains from two Bronze Age (Monteoru culture) sites near Buzău in Romania, in the eastern foothills of the Carpathian Mountains. The results for 54 humans from Sărata Monteoru and 10 from Cârlomăneşti indicate diets that were dominated by $\mathrm{C}_{3}$ terrestrial resources, consistent with the archaeofaunal inventories from the sites and archaeobotanical data from the wider region. Statistically significant differences in the average $\delta^{15} \mathrm{~N}$ values of the two skeletal populations hint at a change in economic practices between early and late phases of the Monteoru culture. Consumer diets at the two sites were quantified using multiple mixing models generated with the Bayesian statistical program FRUITS (Food Reconstruction Using Isotopic Transferred Signals). The model outputs suggest the inhabitants of the later settlement, Sărata Monteoru, were less dependent on animal-derived products and relied more on cereals and legumes for energy and protein, compared to their predecessors at Cârlomăneşti. Based on changes in the faunal record we speculate that dairying may also have increased in importance between the early and later phases of the Monteoru culture.

Key words: Bronze Age, Carpathian Bend, stable isotopes, subsistence, palaeodiets

\section{Introduction}

Along the eastern flank of the Carpathian Mountains, in present-day Romania, is a zone of rolling hills and valleys known as the Sub-Carpathians. During the Bronze Age, this region was inhabited by sedentary farmers of the Monteoru culture. The presence of foreign goods among their archaeological remains hints at a society with trade contacts extending as far as the Baltic and the Aegean (Motzoi-Chicideanu, 1995), yet relatively little is known of the daily life of these people, including their dietary habits.

Palaeodiet studies using stable isotope data have been undertaken in Southeastern Europe since the 1980s (Murray and Schoeninger, 1988), with particularly detailed research on Mesolithic and Early Neolithic populations living along the Lower Danube in the 'Iron Gates' (e.g. Bonsall et al., 1997, 2004; Cook et al., 2001; Borić et al., 2004; Nehlich et al., 2010). For later periods, while there have been studies of Bronze and Iron Age communities along the Adriatic and the Aegean coasts (e.g. Triantaphyllou et al., 2008; Petroutsa and Manolis, 2010; Vika, 2011; Lightfoot et al., 2012, 2015), these periods in the northern Balkans have been comparatively neglected.

Bronze Age economies in southeast Europe can be very broadly characterized by an increase in cultivation intensity and crop diversity (including the spread of millet, a $\mathrm{C}_{4}$ plant) (see Harding, 2000; Motuzaite-Matuzeviciute et al., 2013; Stika and Heiss, 2013) and a shift from caprine to cattle husbandry (Becker, 1999, 2000; Bartosiewicz, 2013). The current study aims to investigate whether similar trends can be observed in the SubCarpathian isotopic record. 
In this paper, we present new stable isotope data for archaeological human and animal remains from two Monteoru culture sites - Sărata Monteoru and Cârlomăneşti - to assess the dietary practices of these Bronze Age communities and to provide quantitative estimates of plant $v s$ animal foods in Monteoru diet.

\section{Archaeological background}

The Monteoru culture is one of the richest Bronze Age cultures in Southeast Europe, and one of the most thoroughly researched (Nestor, 1933; Vulpe, 1995; Motzoi-Chicideanu, 2011). The two sites included in our study, although only $12 \mathrm{~km}$ apart, represent different phases in the evolution of the Monteoru culture (Figure 1).

87

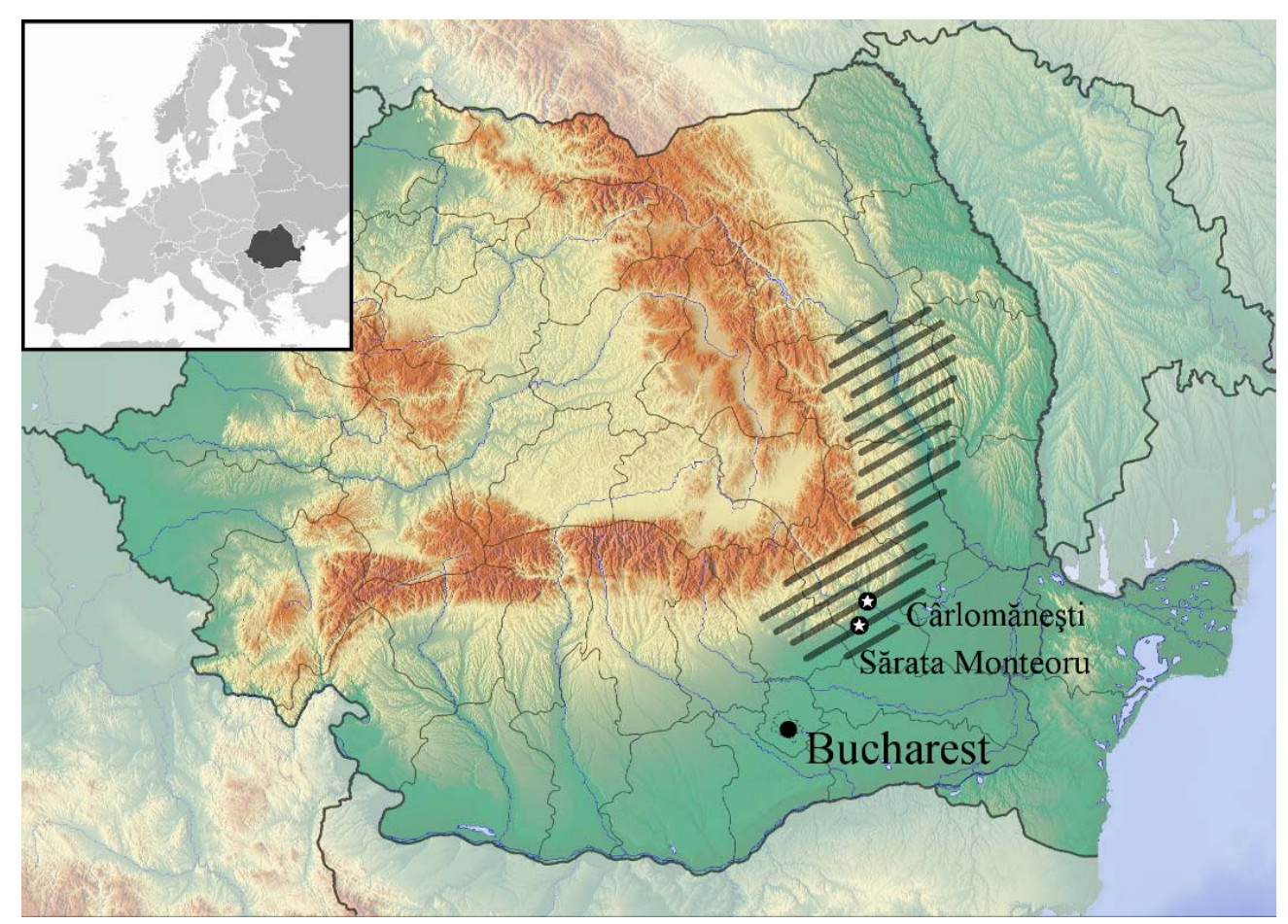

Figure 1. Map of Romania showing the area of the Monteoru culture and the locations of Sărata Monteoru and Cârlomăneşti ('Location map of Romania'by Wikimedia Commons user Dr Brains used under GNU Free Documentation Licence 1.2, modified by $\ddot{U}$. Aguraiuja)

The type site, Sărata Monteoru, is a multi-layer, fortified, hilltop settlement spanning the period from the Early Bronze Age to the end of the Middle Bronze Age, and has several associated cemeteries - three on lower slopes of the same hill, and one on an adjacent hillslope. Only the largest cemetery (no. 4) has been adequately published (Maximilian, 1962; Bârzu, 1989). Pottery typology and ${ }^{14} \mathrm{C}$ dating (four unpublished radiocarbon dates obtained by Mihai Constantinescu) place this cemetery in the middle of the second millennium BC, ca. 1750-1500 cal BC. Although more than half the graves documented in cemetery no. 4 have no grave goods, there are numerous 'rich' graves containing objects made of valuable or exotic materials, such as bronze, gold, glass paste and amber (Bârzu, 1989). 
The site of Cârlomăneşti has a similar environmental setting to Sărata Monteoru,

\section{Stable isotope analysis for dietary reconstruction}

Stable isotopes of carbon and nitrogen, analysed from bone collagen, are commonly used in archaeological research to estimate the proportion of marine $v s$ terrestrial, or plant $v s$ animal resources at both the individual and population level. Carbon isotope ratios $\left(\delta^{13} \mathrm{C}\right)$ can be used to distinguish between marine and terrestrial sources of carbon, but also between diets based on either $\mathrm{C}_{3}$ or $\mathrm{C}_{4}$ plants. Humans living on $\mathrm{C}_{3}$ plants or their consumers have bone collagen $\delta^{13} \mathrm{C}$ values around $-20 \%$, while those relying mainly on $\mathrm{C}_{4}$ resources exhibit much higher values around $-10 \%$; elevated $\delta^{13} \mathrm{C}$ values also result from regular consumption of marine foods (Schoeninger and DeNiro, 1984; Ambrose and DeNiro, 1986; Sealy, 2001). Fish inhabiting freshwater rivers and lakes exhibit widely varying $\mathrm{C}$-isotope signatures. The $\delta^{13} \mathrm{C}$ of fish bones from Mesolithic and Early Neolithic sites in the Iron Gates of the Danube, for example, was found to range between $-26.3 \%$ and $-15.7 \%$ o (Bonsall et al., 1997), while Fuller et al. (2012) reported bone collagen $\delta^{13} \mathrm{C}$ values for freshwater and anadromous fish from historical period sites in Belgium of between $-28.2 \%$ and $-14.1 \%$.

Nitrogen isotope ratios $\left(\delta^{15} \mathrm{~N}\right)$ primarily reflect the trophic level of the organism - with every step up the food chain there occurs an enrichment of ca. $3-6 \%$ in ${ }^{15} \mathrm{~N}$ between the 

2007). This results in plants having the lowest and top carnivores the highest $\delta^{15} \mathrm{~N}$ values. The longest food chains and thus the highest $\delta^{15} \mathrm{~N}$ values are seen in aquatic (both freshwater and marine) ecosystems (Schoeninger and DeNiro, 1984). While $\delta^{15} \mathrm{~N}$ in animal tissues varies in a relatively predictable manner, a broad range of

\section{Materials and methods}

Fifty-four individuals from Sărata Monteoru cemetery no. 4 and 10 individuals from Cârlomăneşti - La Arman were selected for stable $\delta^{13} \mathrm{C}$ and $\delta^{15} \mathrm{~N}$ analysis. A rib bone was sampled from most individuals, although other skeletal elements were used if a rib was not available. Samples were selected to include both sexes, various age groups, and different 'social groups' (based on the presence and amount of grave goods). Additionally, animal bones recovered from graves in cemetery no. $4(\mathrm{n}=17)$ and from the Monteoru period settlement at Cârlomăneşti $(n=39)$ were sampled to provide a regional terrestrial baseline of faunal isotope values. Animal bones from Sărata Monteoru are believed to relate to burial activities (e.g. grave goods or remains of feasting), although they were not documented during the original excavations. Faunal samples from Cârlomăneşti lack a direct connection with the human burials, as they were recovered from the settlement site near the cemetery, but they are assumed to be representative of the type of animal protein consumed by the local inhabitants.

Approximately $1 \mathrm{~g}$ of bone was cut from each of the human and animal bones selected for analysis, using a Dremel multitool fitted with a diamond cutting wheel. Collagen for stable isotope analysis was extracted at the University of Edinburgh Bone Chemistry Laboratory. Bone samples were first cleaned of adhering sediment and 1-2mm removed from exposed surfaces using a sterile scalpel blade, followed by ultrasonication in ultrapure (MilliQ ${ }^{\mathrm{TM}}$ ) water. After drying, the cleaned samples were weighed and then subjected to standard acid/base/acid (ABA) pre-treatment at room temperature, comprising demineralization in $1 \mathrm{M} \mathrm{HCl}$, followed by $0.2 \mathrm{M} \mathrm{NaOH}$ wash for 20 minutes to remove humic acids, and a final $1 \mathrm{M} \mathrm{HCl}$ wash for 1 hour to remove any secondary carbonates that may have formed during $\mathrm{NaOH}$ treatment - after each step, the samples were rinsed three times with ultrapure water. The residue was gelatinized in a $\mathrm{pH} 3$ solution at $80^{\circ} \mathrm{C}$ for approximately 20 hours. The resulting solution was filtered, evaporated until about $10 \mathrm{ml}$ remained, freeze-dried, then weighed to determine percent yield. 
Collagen samples were measured for $\delta^{13} \mathrm{C}$ and $\delta^{15} \mathrm{~N}$ at the NERC Isotope Geosciences Laboratory facility at Keyworth (UK), using a Continuous Flow-Elemental AnalysisIsotope Ratio Mass Spectrometry (CF-EA-IRMS) consisting of an elemental analyser (Flash/EA) coupled to a ThermoFinniganDelta ${ }^{\text {Plus }}$ XL isotope ratio mass spectrometer via a ConFlo III interface. Collagen carbon and nitrogen isotope ratios are reported in per mil (\%o) relative to VPDB and AIR standards, respectively. $\delta^{13} \mathrm{C}$ and $\delta^{15} \mathrm{~N}$ ratios were calibrated using an in-house reference material M1360p (powdered gelatine from British Drug Houses) with expected delta values of $-20.32 \%$ (calibrated against CH7, IAEA) and $+8.12 \%$ (calibrated against N-1 and N-2, IAEA) for C and N, respectively. Analyses were run in duplicate and the average 1-sigma standard deviation of the duplicates was $\delta^{13} \mathrm{C}= \pm 0.06 \%$ and $\delta^{15} \mathrm{~N}= \pm 0.05 \%$. The 1 -sigma reproducibility for mass spectrometry

\section{Results}

The stable isotope data for the human and animal bone samples analysed are presented in Tables 1 \& 2 and Figures 2 \& 3.

214 Collagen yields for all samples were $>1 \%$ and atomic $\mathrm{C}: \mathrm{N}$ ratios between 3.2 and 3.4, indicative of well-preserved collagen (van Klinken, 1999). Most samples also had elemental concentrations within the range of $\geq 30 \%$ for $\% \mathrm{C}$ and $\geq 10 \%$ for $\% \mathrm{~N}$ defined by van Klinken (1999).

218 In three cases, $\% \mathrm{C}$ and $\% \mathrm{~N}$ were below that range, but still within the accepted lower limits of 13 for $\% \mathrm{C}$ and 5 for $\% \mathrm{~N}$ (Ambrose, 1990). Since these samples also had C:N ratios indicative of well-preserved collagen, and the values themselves do not seem abnormal, they were not discarded. 


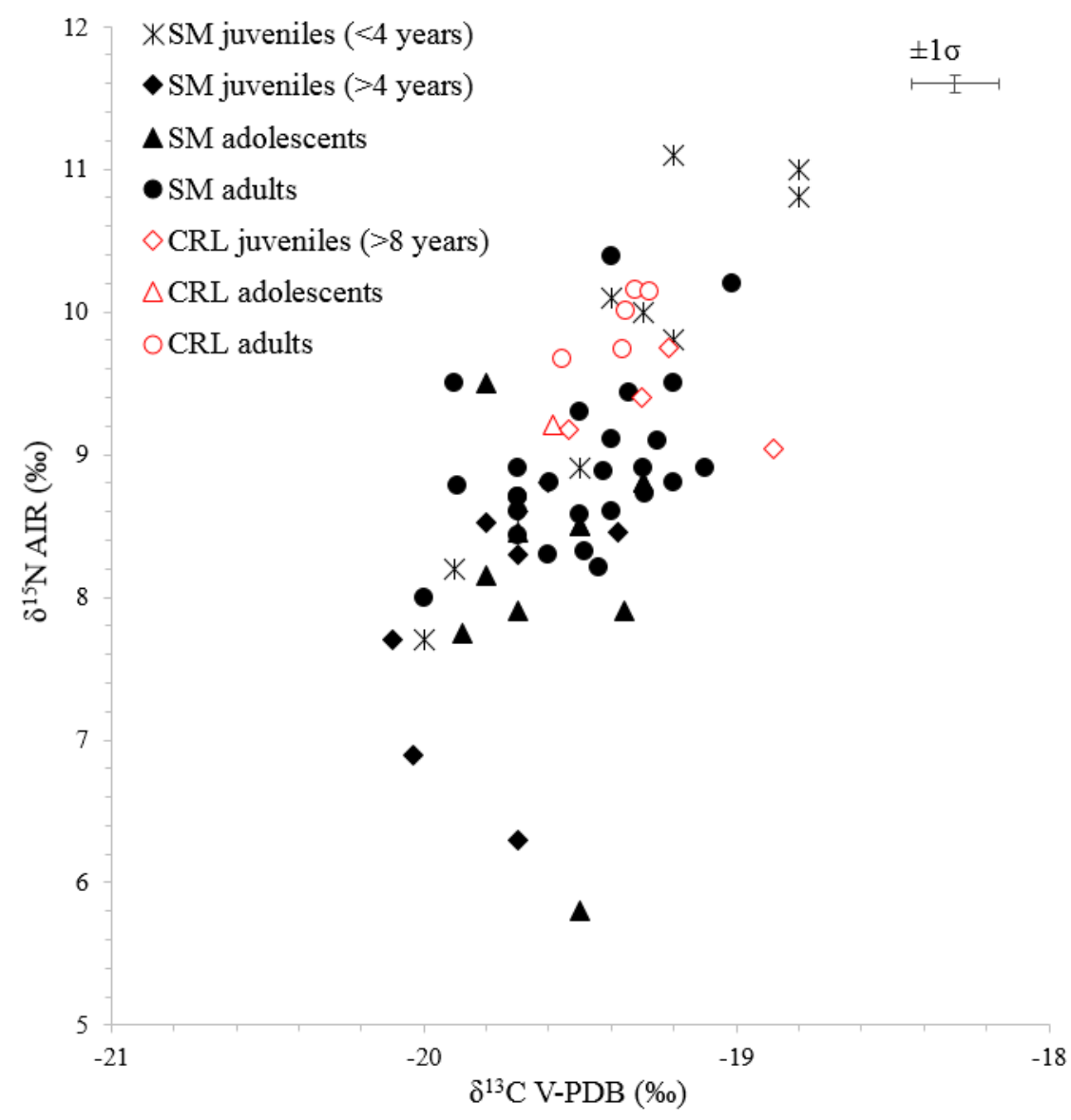

224 Figure 2. Scatterplot of human $\delta^{13} C$ and $\delta^{15} N$ values. $S M=$ Sărata Monteoru, $225 \quad C R L=$ Cârlomăneşti 


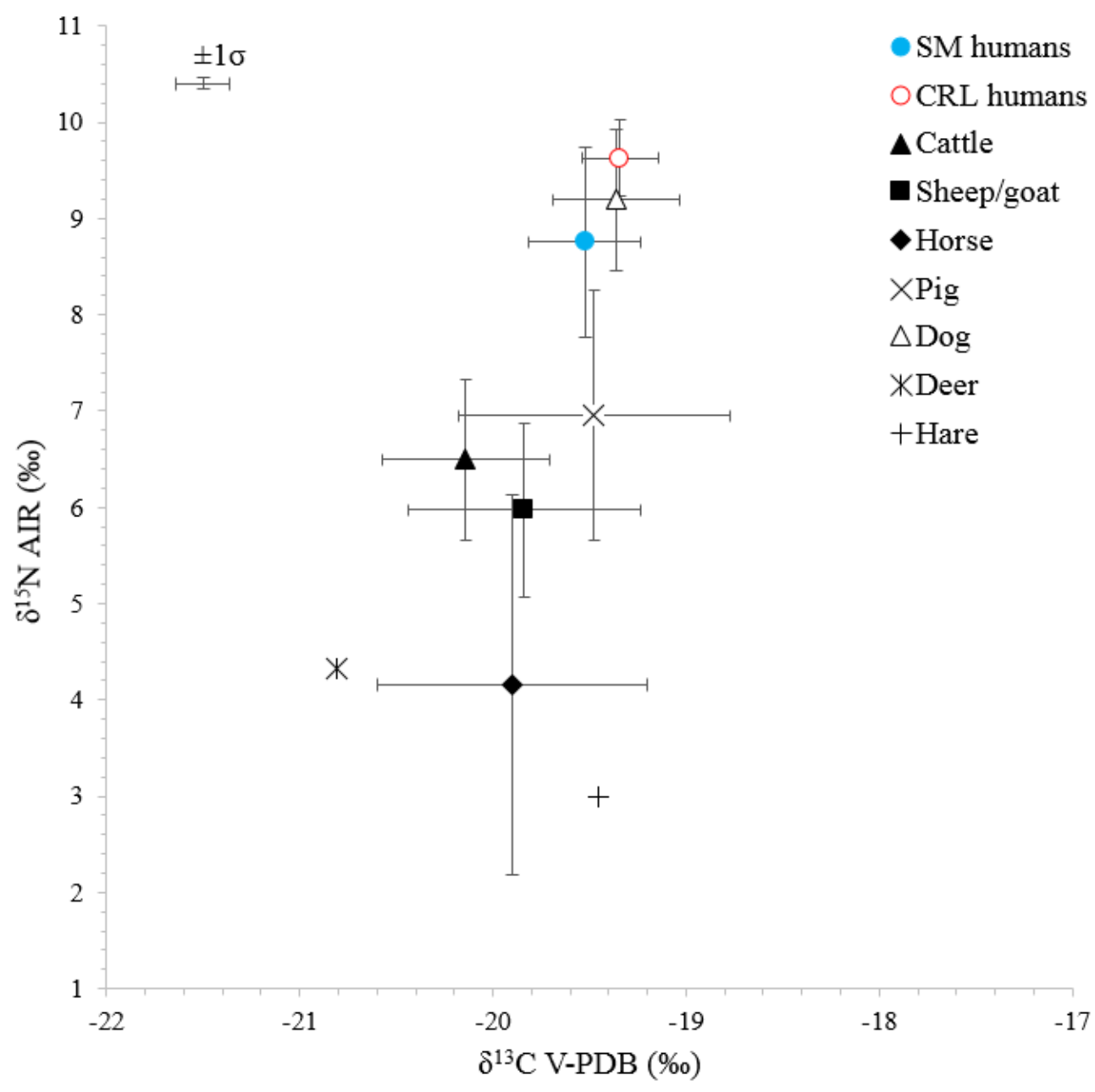

Figure 3. Scatterplot of human and animal average $\delta^{13} C$ and $\delta^{15} N$ values, $1 S D$ marked with error bars. Deer and hare ratios presented as individual values. SM=Sărata Monteoru, $C R L=$ Cârlomăneşti

232 Table 1. Stable isotope results for human bone collagen from Sărata Monteoru and 233 Cârlomăneşti.

\begin{tabular}{|lcccccccc|}
\hline $\begin{array}{c}\text { Burial } \\
\text { no. }\end{array}$ & Age & Sex & $\begin{array}{c}\text { Grave } \\
\text { goods }\end{array}$ & $\begin{array}{c}\delta^{13} \mathrm{C}_{\text {V-PDB }} \\
\% \text { o }\end{array}$ & $\begin{array}{c}\delta^{15} \mathrm{~N}_{\text {AIR }} \\
\% \text { o }\end{array}$ & $\% \mathrm{C}$ & $\% \mathrm{~N}$ & $\begin{array}{c}\text { at } \\
\text { C:N }\end{array}$ \\
\hline \multicolumn{7}{c}{ Sărata Monteoru } \\
\hline 12 & $9-11$ & N/A & Rich & -19.7 & 6.3 & 41.6 & 14.7 & 3.3 \\
13 & Adult & F & No & -19.9 & 9.5 & 29.6 & 10.4 & 3.3 \\
24 & $1.5-2$ & N/A & No & -19.2 & 9.8 & 41.1 & 14.5 & 3.3 \\
$35 \mathrm{a}$ & $17-19$ & F & Rich & -19.5 & 8.5 & 39.1 & 13.9 & 3.3 \\
$35 \mathrm{~b}$ & $1.5-2$ & N/A & Rich & -19.2 & 11.1 & 41.3 & 14.8 & 3.3 \\
40 & $17-19$ & F & Rich & -19.5 & 5.8 & 39.4 & 13.8 & 3.3 \\
41 & $7-9$ & N/A & No & -20.1 & 7.7 & 42.0 & 14.8 & 3.3 \\
46 & $16-18$ & N/A & N/A & -19.8 & 9.5 & 32.7 & 11.4 & 3.4 \\
48 & Adult & $?$ & Few & -19.7 & 8.4 & 41.4 & 14.6 & 3.3 \\
50 & $1-3$ & N/A & Few & -18.8 & 10.8 & 36.5 & 12.8 & 3.3 \\
53 & Adult & F & No & -19.3 & 8.7 & 40.7 & 14.6 & 3.3 \\
\hline
\end{tabular}




\begin{tabular}{|c|c|c|c|c|c|c|c|c|}
\hline $54 a$ & Adult & $\mathrm{F}$ & No & -19.7 & 8.7 & 40.3 & 14.4 & 3.3 \\
\hline 61 & $17-19$ & $\mathrm{~F}$ & No & -19.4 & 7.9 & 42.1 & 14.9 & 3.3 \\
\hline 62 & Adult & M & No & -19.4 & 9.1 & 41.7 & 14.7 & 3.3 \\
\hline 63 & $19-21$ & $\mathrm{~F}$ & Rich & -19.9 & 7.8 & 40.4 & 14.2 & 3.3 \\
\hline 64 & Adult & $\mathrm{F}$ & No & -19.6 & 8.8 & 42.1 & 14.8 & 3.3 \\
\hline 65 & Adult & $?$ & No & -19.3 & 9.1 & 41.6 & 14.8 & 3.3 \\
\hline 66 & Adult & $?$ & No & -19.5 & 8.3 & 41.4 & 14.7 & 3.3 \\
\hline 68 & Adult & M & Few & -19.4 & 8.9 & 41.3 & 14.7 & 3.3 \\
\hline 69 & $15-17$ & $?$ & Few & -19.3 & 8.8 & 40.7 & 14.4 & 3.3 \\
\hline 70 & $8-10$ & N/A & No & -19.4 & 8.5 & 41.6 & 14.8 & 3.3 \\
\hline 71 & Adult & $\mathrm{M}$ & Rich & -19.1 & 8.9 & 41.5 & 14.6 & 3.3 \\
\hline 72 & $7-9$ & N/A & Rich & -20.0 & 6.9 & 41.5 & 14.6 & 3.3 \\
\hline 74 & Adult & $\mathrm{F}$ & No & -19.0 & 10.2 & 41.2 & 14.4 & 3.3 \\
\hline $75 a$ & Adult & F & No & -19.2 & 9.5 & 41.7 & 14.7 & 3.3 \\
\hline $75 b$ & $1.5-2$ & N/A & No & -18.8 & 11.0 & 39.2 & 13.9 & 3.3 \\
\hline 77 & Adult & $\mathrm{M}$ & Few & -19.3 & 8.9 & 39.9 & 14.0 & 3.3 \\
\hline 78 & Adult & M & Few & -19.6 & 8.3 & 40.0 & 14.2 & 3.3 \\
\hline 79 & Adult & M & No & -19.7 & 8.6 & 40.4 & 14.2 & 3.3 \\
\hline 80 & $2-4$ & N/A & Few & -19.4 & 10.1 & 39.5 & 13.7 & 3.4 \\
\hline 81 & Adult & $?$ & Few & -19.4 & 8.2 & 41.1 & 14.6 & 3.3 \\
\hline 82 & $15-17$ & $?$ & Few & -19.5 & 8.5 & 39.9 & 14.0 & 3.3 \\
\hline 85 & Adult & $\mathrm{F}$ & No & -20.0 & 8.0 & 40.4 & 14.2 & 3.3 \\
\hline 86 & $18-20$ & M & No & -19.7 & 8.5 & 42.2 & 14.8 & 3.3 \\
\hline 88 & $7-9$ & N/A & Rich & -19.7 & 8.6 & 40.7 & 14.3 & 3.3 \\
\hline $90 \mathrm{~b}$ & $1.5-2$ & N/A & No & -19.3 & 10.0 & 38.2 & 13.5 & 3.3 \\
\hline 101 & Adult & $\mathrm{F}$ & Few & -19.5 & 8.6 & 41.1 & 14.5 & 3.3 \\
\hline 102 & $15-17$ & $?$ & No & -19.8 & 8.1 & 39.3 & 13.8 & 3.3 \\
\hline 105 & Adult & $\mathrm{F}$ & Rich & -19.7 & 8.9 & 42.0 & 14.8 & 3.3 \\
\hline 106 & Adult & $\mathrm{F}$ & No & -19.4 & 8.6 & 41.2 & 14.5 & 3.3 \\
\hline 107 & Adult & $\mathrm{F}$ & Rich & -19.9 & 8.8 & 42.2 & 14.8 & 3.3 \\
\hline 108 & Adult & M & No & -19.4 & 10.4 & 42.2 & 14.8 & 3.3 \\
\hline 112 & $18-20$ & M & No & -19.3 & 8.8 & 40.8 & 14.5 & 3.3 \\
\hline 116 & $3-5$ & N/A & No & -19.5 & 8.9 & 39.4 & 13.9 & 3.3 \\
\hline 117 & $2-3$ & $\mathrm{~N} / \mathrm{A}$ & No & -20.0 & 7.7 & 39.9 & 13.9 & 3.3 \\
\hline 119 & $5-6$ & N/A & Few & -19.7 & 8.3 & 40.8 & 14.4 & 3.3 \\
\hline 120 & $9-10$ & N/A & No & -19.6 & 8.8 & 40.0 & 14.0 & 3.3 \\
\hline 123 & $17-19$ & M & No & -19.7 & 7.9 & 39.0 & 13.7 & 3.3 \\
\hline 124 & $2-4$ & N/A & No & -19.9 & 8.2 & 40.3 & 14.1 & 3.3 \\
\hline 126 & Adult & M & No & -19.5 & 9.3 & 41.3 & 14.7 & 3.3 \\
\hline 127 & Adult & M & No & -19.2 & 8.8 & 41.2 & 14.5 & 3.3 \\
\hline 128 & $8-12$ & N/A & No & -19.8 & 8.5 & 40.8 & 14.3 & 3.3 \\
\hline 134 & Adult & $\mathrm{F}$ & No & -19.7 & 8.7 & 39.0 & 13.6 & 3.3 \\
\hline 135 & Adult & $\mathrm{F}$ & No & -19.3 & 9.4 & 40.4 & 14.2 & 3.3 \\
\hline \multicolumn{4}{|c|}{ Site average } & $-19.5 \pm 0.3$ & $8.8 \pm 1.0$ & & & \\
\hline \multicolumn{9}{|c|}{ Cârlomăneşti } \\
\hline 1 & Adult & $\mathrm{F}$ & Rich & -19.6 & 9.7 & 42.9 & 15.1 & 3.3 \\
\hline 2 & $13-15$ & $?$ & Few & -19.6 & 9.2 & 42.5 & 15.0 & 3.3 \\
\hline 5 & Adult & M & Few & -19.4 & 9.7 & 42.4 & 14.9 & 3.3 \\
\hline
\end{tabular}




\begin{tabular}{|lcclccccc|}
19 & Adult & F & Few & -19.3 & 10.2 & 42.0 & 14.7 & 3.3 \\
24 & $10-12$ & N/A & Few & -19.5 & 9.2 & 42.4 & 15.0 & 3.3 \\
51 & $9-13$ & N/A & Rich & -19.2 & 9.7 & 41.9 & 14.9 & 3.3 \\
58 & $8-9$ & N/A & Few & -18.9 & 9.0 & 42.5 & 15.1 & 3.3 \\
$80 \mathrm{a}$ & Adult & F & Rich & -19.3 & 10.1 & 42.9 & 15.2 & 3.3 \\
103 & Adult & F & Few & -19.4 & 10.0 & 38.0 & 13.3 & 3.3 \\
$105 \mathrm{a}$ & $8-9$ & N/A & Few & -19.3 & 9.4 & 41.6 & 15.0 & 3.3 \\
\hline \multicolumn{7}{|c}{ Site average } & $\mathbf{- 1 9 . 3 \pm 0 . 2}$ & $\mathbf{9 . 6 \pm 0 . 4}$ \\
\hline
\end{tabular}

Table 2. Stable isotope results for animal bone collagen from Sărata Monteoru and

236 Cârlomăneşti. Notes: 1. Each bone sample was given a unique identification code; 2. The description 'Sheep/goat' reflects the difficulty in distinguishing sheep (Ovis aries) from goats (Capra hircus) in the animal bone assemblages from the two sites.

\begin{tabular}{|c|c|c|c|c|c|c|c|c|}
\hline $\begin{array}{l}\text { Sample } \\
\text { No. }^{1}\end{array}$ & Animal $^{2}$ & Species & Comments & $\begin{array}{l}\delta^{13} \mathrm{C}_{\mathrm{V}} \\
\mathrm{PDB} \%\end{array}$ & $\delta^{15} \mathrm{~N}_{\mathrm{AIR}} \%$ & $\% \mathrm{C}$ & $\% \mathrm{~N}$ & $\begin{array}{c}\text { at } \\
\mathrm{C}: \mathrm{N}\end{array}$ \\
\hline \multicolumn{9}{|c|}{ Sărata Monteoru } \\
\hline 2-SM & Sheep/goat & $\begin{array}{l}\text { Ovis aries or } \\
\text { Capra hircus }\end{array}$ & \multirow{17}{*}{$\begin{array}{l}\text { Young } \\
\text { individual }\end{array}$} & -19.4 & 6.1 & 42.2 & 14.8 & 3.3 \\
\hline 3-SM & Sheep/goat & $\begin{array}{l}\text { Ovis aries or } \\
\text { Capra hircus }\end{array}$ & & -20.0 & 5.9 & 40.0 & 14.1 & 3.3 \\
\hline 4-SM & Pig & $\begin{array}{l}\text { Sus scrofa } \\
\text { domesticus }\end{array}$ & & -19.9 & 7.4 & 40.5 & 14.4 & 3.3 \\
\hline 5-SM & Pig & $\begin{array}{l}\text { Sus scrofa } \\
\text { domesticus }\end{array}$ & & -19.1 & 9.8 & 39.6 & 13.5 & 3.4 \\
\hline 6-SM & Sheep/goat & $\begin{array}{l}\text { Ovis aries or } \\
\text { Capra hircus }\end{array}$ & & -19.1 & 6.4 & 41.8 & 14.9 & 3.3 \\
\hline 7-SM & Sheep/goat & $\begin{array}{l}\text { Ovis aries or } \\
\text { Capra hircus }\end{array}$ & & -19.6 & 5.9 & 41.1 & 14.4 & 3.3 \\
\hline 8-SM & Cattle & Bos taurus & & -20.0 & 6.6 & 38.1 & 13.6 & 3.3 \\
\hline 9-SM & Pig & $\begin{array}{l}\text { Sus scrofa } \\
\text { domesticus }\end{array}$ & & -19.5 & 7.6 & 40.1 & 14.1 & 3.3 \\
\hline 10-SM & Cattle & Bos taurus & & -20.0 & 6.3 & 39.9 & 14.1 & 3.3 \\
\hline 11-SM & Sheep/goat & $\begin{array}{l}\text { Ovis aries or } \\
\text { Capra hircus }\end{array}$ & & -19.0 & 5.4 & 41.1 & 14.6 & 3.3 \\
\hline 13-SM & Sheep/goat & $\begin{array}{l}\text { Ovis aries or } \\
\text { Capra hircus }\end{array}$ & & -18.9 & 5.7 & 34.3 & 12.1 & 3.3 \\
\hline 14-SM & Cattle & Bos taurus & & -20.7 & 7.8 & 41.4 & 14.7 & 3.3 \\
\hline 15-SM & Cattle & Bos taurus & & -19.5 & 6.4 & 41.1 & 14.5 & 3.3 \\
\hline 16-SM & Dog & $\begin{array}{c}\text { Canis } \\
\text { familiaris }\end{array}$ & & -19.2 & 8.4 & 42.7 & 15.0 & 3.3 \\
\hline 19-SM & Sheep/goat & $\begin{array}{l}\text { Ovis aries or } \\
\text { Capra hircus }\end{array}$ & & -20.2 & 7.4 & 40.4 & 14.1 & 3.4 \\
\hline 20-SM & Cattle & Bos taurus & & -20.5 & 6.4 & 40.1 & 14.0 & 3.4 \\
\hline 21-SM & Horse & Equus caballus & & -19.9 & 6.4 & 41.1 & 14.4 & 3.3 \\
\hline \multicolumn{9}{|c|}{ Cârlomăneşti } \\
\hline 22-CRL & Cattle & Bos taurus & & -20.6 & 6.5 & 42.0 & 14.9 & 3.3 \\
\hline 24-CRL & Sheep & Ovis aries & & -20.1 & 5.8 & 41.8 & 14.9 & 3.3 \\
\hline 25-CRL & Horse & Equus caballus & & -19.6 & 4.8 & 16.0 & 5.5 & 3.4 \\
\hline 26-CRL & Sheep/goat & $\begin{array}{l}\text { Ovis aries or } \\
\text { Capra hircus }\end{array}$ & $\begin{array}{l}\text { With canid } \\
\text { gnaw marks }\end{array}$ & -19.9 & 6.0 & 41.9 & 14.9 & 3.3 \\
\hline 29-CRL & Horse & Equus caballus & & -19.5 & 2.8 & 42.4 & 15.0 & 3.3 \\
\hline
\end{tabular}




\begin{tabular}{|c|c|c|c|c|c|c|c|c|}
\hline 30-CRL & Cattle & Bos taurus & $\begin{array}{c}\text { Young } \\
\text { individual }\end{array}$ & -20.3 & 7.7 & 36.7 & 13.0 & 3.3 \\
\hline 31-CRL & Pig & $\begin{array}{l}\text { Sus scrofa } \\
\text { domesticus }\end{array}$ & & -13.5 & 6.2 & 42.4 & 15.3 & 3.2 \\
\hline 32-CRL & Pig & $\begin{array}{l}\text { Sus scrofa } \\
\text { domesticus }\end{array}$ & $\begin{array}{l}\text { With canid } \\
\text { gnaw marks }\end{array}$ & -18.5 & 5.2 & 41.7 & 15.1 & 3.2 \\
\hline 33-CRL & Deer & Cervus sp. & & -20.8 & 4.3 & 28.8 & 10.2 & 3.3 \\
\hline 34-CRL & Pig & $\begin{array}{l}\text { Sus scrofa } \\
\text { domesticus }\end{array}$ & & -19.5 & 7.9 & 26.2 & 9.1 & 3.4 \\
\hline 35-CRL & Dog & $\begin{array}{c}\text { Canis } \\
\text { familiaris }\end{array}$ & & -20.0 & 9.8 & 39.9 & 14.3 & 3.3 \\
\hline 36-CRL & Pig & $\begin{array}{l}\text { Sus scrofa } \\
\text { domesticus }\end{array}$ & & -18.6 & 6.3 & 41.4 & 14.9 & 3.2 \\
\hline 37-CRL & Cattle & Bos taurus & & -20.2 & 5.6 & 41.7 & 15.0 & 3.2 \\
\hline 39-CRL & Sheep/goat & $\begin{array}{l}\text { Ovis aries or } \\
\text { Capra hircus }\end{array}$ & & -16.4 & 6.8 & 34.5 & 12.4 & 3.3 \\
\hline 40-CRL & Sheep/goat & $\begin{array}{l}\text { Ovis aries or } \\
\text { Capra hircus }\end{array}$ & & -22.1 & 6.4 & 42.5 & 15.5 & 3.2 \\
\hline 41-CRL & Pig & $\begin{array}{l}\text { Sus scrofa } \\
\text { domesticus }\end{array}$ & & -20.6 & 6.1 & 42.5 & 15.3 & 3.3 \\
\hline 43-CRL & Pig & $\begin{array}{l}\text { Sus scrofa } \\
\text { domesticus }\end{array}$ & & -20.5 & 5.8 & 42.9 & 15.1 & 3.3 \\
\hline 44-CRL & Dog & $\begin{array}{c}\text { Canis } \\
\text { familiaris }\end{array}$ & & -19.2 & 9.0 & 42.0 & 15.0 & 3.3 \\
\hline 45-CRL & Hare & Lepus sp. & & -19.5 & 3.0 & 42.4 & 15.0 & 3.3 \\
\hline 46-CRL & Cattle & Bos taurus & & -19.5 & 5.3 & 41.4 & 14.8 & 3.3 \\
\hline 47-CRL & Cattle & Bos taurus & & -20.6 & 8.2 & 33.4 & 11.6 & 3.4 \\
\hline 48-CRL & Sheep/goat & $\begin{array}{l}\text { Ovis aries or } \\
\text { Capra hircus }\end{array}$ & & -20.3 & 7.6 & 41.7 & 14.7 & 3.3 \\
\hline 49-CRL & Horse & Equus caballus & & -20.9 & 3.2 & 40.5 & 14.4 & 3.3 \\
\hline 51-CRL & Cattle & Bos Taurus & & -20.4 & 6.1 & 41.4 & 14.7 & 3.3 \\
\hline 52-CRL & Dog & $\begin{array}{c}\text { Canis } \\
\text { familiaris }\end{array}$ & & -19.5 & 9.7 & 41.7 & 14.9 & 3.3 \\
\hline 53-CRL & Sheep/goat & $\begin{array}{l}\text { Ovis aries or } \\
\text { Capra hircus }\end{array}$ & $\begin{array}{l}\text { Young } \\
\text { individual }\end{array}$ & -20.6 & 6.1 & 41.8 & 14.8 & 3.3 \\
\hline 55-CRL & Sheep/goat & $\begin{array}{l}\text { Ovis aries or } \\
\text { Capra hircus }\end{array}$ & $\begin{array}{l}\text { Young } \\
\text { individual }\end{array}$ & -17.1 & 7.9 & 42.1 & 14.9 & 3.3 \\
\hline 56-CRL & Dog & $\begin{array}{l}\text { Canis } \\
\text { familiaris }\end{array}$ & & -19.4 & 7.9 & 41.6 & 14.7 & 3.3 \\
\hline 57-CRL & Pig & $\begin{array}{l}\text { Sus scrofa } \\
\text { domesticus }\end{array}$ & & -19.1 & 6.6 & 41.9 & 14.9 & 3.3 \\
\hline 58-CRL & Pig & $\begin{array}{l}\text { Sus scrofa } \\
\text { domesticus }\end{array}$ & & -19.4 & 6.7 & 41.6 & 14.7 & 3.3 \\
\hline 59-CRL & Cattle & Bos taurus & & -19.4 & 6.1 & 39.7 & 14.1 & 3.3 \\
\hline 60-CRL & Cattle & Bos taurus & & -20.2 & 7.0 & 38.1 & 13.3 & 3.3 \\
\hline 61-CRL & Cattle & Bos taurus & & -20.5 & 6.1 & 42.1 & 15.0 & 3.3 \\
\hline 62-CRL & Dog & Canis sp. & $\begin{array}{c}\text { Large } \\
\text { individual (or } \\
\text { wolf) }\end{array}$ & -19.5 & 8.9 & 41.4 & 14.7 & 3.3 \\
\hline 63-CRL & Dog & $\begin{array}{c}\text { Canis } \\
\text { familiaris }\end{array}$ & & -19.0 & 9.9 & 42.1 & 15.0 & 3.3 \\
\hline 64-CRL & Cattle & Bos taurus & & -19.8 & 5.5 & 41.8 & 14.9 & 3.3 \\
\hline 65-CRL & Sheep/goat & $\begin{array}{l}\text { Ovis aries or } \\
\text { Capra hircus }\end{array}$ & & -20.5 & 4.5 & 41.8 & 14.8 & 3.3 \\
\hline 66-CRL & Dog & $\begin{array}{l}\text { Canis } \\
\text { familiaris }\end{array}$ & & -19.1 & 9.8 & 42.6 & 15.0 & 3.3 \\
\hline 67-CRL & Sheep/goat & Ovis aries or & With canid & -20.4 & 4.9 & 42.2 & 15.0 & 3.3 \\
\hline
\end{tabular}




\subsection{Sărata Monteoru}

The average isotope values for all Sărata Monteoru individuals $(n=54)$ were $-19.5 \pm 0.3 \%$ o for $\delta^{13} \mathrm{C}$ and $+8.8 \pm 1.0 \%$ for $\delta^{15} \mathrm{~N}$ (Table 1, Figure 3). This is consistent with a terrestrial diet based on $\mathrm{C}_{3}$ plants and plant consumers.

While the $\delta^{13} \mathrm{C}$ range is relatively small (-20.1\% to $-18.8 \%$ ), there is significant variation in $\delta^{15} \mathrm{~N}$ values (from $+5.8 \%$ to $+11.1 \%$ ). The highest and lowest $\delta^{15} \mathrm{~N}$ values generally belong to juveniles (here defined as between 0-15 years), although excluding the juveniles has little effect on mean $\delta^{13} \mathrm{C}$ and $\delta^{15} \mathrm{~N}$ values $(-19.5 \%$ o $\pm 0.2 \%$ and $+8.7 \%$ o $\pm 0.8 \%$, respectively).

Burial no. 40 (17-19-year-old female) is an outlier, with an exceptionally low $\delta^{15} \mathrm{~N}$ value of $+5.8 \%$. The quality indicators for this sample are within accepted limits and, if not due to contamination or measurement error, this result would imply an almost exclusively plant-based diet. For modern vegans, hair keratin $\delta^{15} \mathrm{~N}$ values as low as $+5.5 \%$ o have been reported (Petzke et al., 2005; see also O'Connell and Hedges, 1999), but since human hair has been shown to be on average $0.86 \%$ lower in $\delta^{15} \mathrm{~N}$ than bone collagen from the same individual (O'Connell et al., 2001), none of the modern vegans would likely have had bone collagen values as low as that seen in the Sărata Monteoru outlier.

Among adolescents (here defined as from the age 15 onwards) and adults, 17 females and 12 males could be identified. The average values for adult females $(-19.6 \%$ $\pm 0.3 \%$; $+8.6 \%$ o $\pm 1.0 \%$ o $)$ and males $(-19.4 \%$ $\pm 0.2 \%$; $+8.9 \%$ $\pm 0.6 \%$ ) were similar; removing the outlier (burial 40) mentioned above from the female group would result in almost identical mean $\delta^{15} \mathrm{~N}$ values for both groups (mean female $\delta^{15} \mathrm{~N}$ without the outlier is $+8.8 \% \pm 0.6$ ). With or without the outlier, there were no statistically significant differences in $\delta^{13} \mathrm{C}$ or $\delta^{15} \mathrm{~N}$ related to the sex of the individual (Mann-Whitney U test, $\mathrm{p}>0.05$ for both variables).

$\delta^{13} \mathrm{C}$ and $\delta^{15} \mathrm{~N}$ values also showed no statistically significant differences between juveniles, adolescents and adults (Kruskal-Wallis $\mathrm{H}$ test, $\mathrm{p}>0.05$ for both variables). However, the difference would be statistically significant if juveniles were separated into two groups: those under 4 years old ( $\mathrm{n}=9$, mean values of $-19.3 \%$ and $+9.7 \%$ ); and those over 4 years old $(n=8$, mean values of $-19.8 \%$ and $+7.9 \%$ ) (Kruskal-Wallis $H$ test, $\mathrm{H}=7.392$, d.f. $=2, \mathrm{p}=0.025$ for $\delta^{13} \mathrm{C}$, and $\mathrm{H}=10.739$, d.f. $=2, \mathrm{p}=0.005$ for $\delta^{15} \mathrm{~N}$; post hoc analyses showed the difference to lie between the younger and older juvenile groups for both $\delta^{13} \mathrm{C}[\mathrm{p}=0.022]$ and $\left.\delta^{15} \mathrm{~N}[\mathrm{p}=0.003]\right)$.

The higher $\delta^{15} \mathrm{~N}$ (and $\delta^{13} \mathrm{C}$ ) values of infants reflect the well-documented breastfeeding effect (see Fuller et al., 2006). Here, infants display $\delta^{15} \mathrm{~N}$ values up to $2.5 \%$ higher (and up to $1.2 \%$ for $\delta^{13} \mathrm{C}$ ) compared to the female mean, with elevated values starting to drop from age 3 years onwards.

The lower $\delta^{15} \mathrm{~N}$ values for older juveniles have been documented in other studies (e.g. Richards et al., 2002; Nitsch et al., 2011), and are sometimes attributed to the childhood diet containing lower trophic-level foods (e.g. cereals) as weaning foods (Tsutaya and Yoneda, 2013). An alternative explanation for the observed lower $\delta^{15} \mathrm{~N}$ values of older children involves the influence of positive nitrogen balance during growth (Katzenberg and Lovell, 1999; Fuller et al., 2004). However, Waters-Rist and Katzenberg (2010) 
concluded that the effects of growth (i.e. positive nitrogen balance) are too minor to significantly affect $\delta^{15} \mathrm{~N}$ values in juvenile bone collagen.

The quality and quantity of grave goods has traditionally been associated with social

\subsection{Cârlomăneşti}

The average isotope values for all Cârlomăneşti individuals $(\mathrm{n}=10)$ were $-19.3 \%$ o $( \pm 0.2 \%$ ) for $\delta^{13} \mathrm{C}$ and $+9.6 \%$ o $\left( \pm 0.4 \%\right.$ ) for $\delta^{15} \mathrm{~N}$ (Table 1, Figure 3). Cârlomăneşti human values display a more restricted range compared to Sărata Monteoru, but this may be an effect of the small sample size. Given the small data set, no statistical analyses were conducted; however, it is worth noting that the $\delta^{13} \mathrm{C}$ and $\delta^{15} \mathrm{~N}$ values of the one adult male individual fall entirely within the range of the four females from the same site. The Cârlomăneşti sample set did not include any infants (i.e. those under 4 years of age), but mean values for older juveniles $(n=4)$ and adults/adolescents $(n=6)$ follow a similar trend to Sărata Monteoru where adult $\delta^{15} \mathrm{~N}$ values are slightly higher than those of younger individuals. All individuals analysed from Cârlomăneşti were buried with grave goods, but there are no clear differences in the isotope values of burials according to the number or type of items included in the grave.

\subsection{Faunal isotope values}

Cârlomăneşti faunal samples ( $\mathrm{n}=38)$ showed a much wider range of $\delta^{13} \mathrm{C}$ and $\delta^{15} \mathrm{~N}$ values $\left(-13.5 \%\right.$ to $-22.1 \%$ for $\delta^{13} \mathrm{C},+2.8 \%$ o to $+9.9 \%$ for $\left.\delta^{15} \mathrm{~N}\right)$ compared to Sărata Monteoru $(n=17)\left(-18.9 \%\right.$ o to $-20.7 \%$ o for $\delta^{13} \mathrm{C},+5.4 \%$ to $+9.8 \%$ o for $\left.\delta^{15} \mathrm{~N}\right)$, however, the two ranges overlap and the mean values for livestock (cattle, caprines, pigs) from the two sites are not statistically different (Cârlomăneşti $-19.6 \%$ o $[ \pm 1.7 \%$ ],$+6.3 \%$ [ $[ \pm 0.9 \%$ ]; Sărata Monteoru $-19.7 \%$ o $\left[ \pm 0.5 \%\right.$ o], $+6.7 \%$ o $\left[ \pm 1.1 \%\right.$ o], for $\delta^{13} \mathrm{C}$ and $\delta^{15} \mathrm{~N}$, respectively) (Table 2). The greater range for Cârlomăneşti may be influenced by the larger sample size, or by the archaeological material originating from various Monteoru-era layers of the settlement site (and thus potentially representing a longer period).

There is considerable variation in faunal $\delta^{15} \mathrm{~N}$ values for both sites, and in $\delta^{13} \mathrm{C}$ values for Cârlomăneşti. Some of the higher $\delta^{15} \mathrm{~N}$ values may originate from suckling animals (which would thus display the nursing effect), or from selective consumption of manured plants with elevated $\delta^{15} \mathrm{~N}$ values. The lowest $\delta^{15} \mathrm{~N}$ values were seen in wild herbivores but also in (some) horses. $\delta^{13} \mathrm{C}$ values for herbivores were generally consistent with diets based on $\mathrm{C}_{3}$ plants. However, there are several outliers, all from Cârlomăneşti: two caprines (sheep or goat) have $\delta^{13} \mathrm{C}$ values of $-16.4 \%$ and $-17.1 \%$, which suggest a significant contribution to 
diet from $\mathrm{C}_{4}$ resources; while one pig has the highest $\delta^{13} \mathrm{C}$ value $(-13.5 \%$ ) of any sample

\subsection{Inter-site differences}

The mean isotope values for all humans from Sărata Monteoru $\left(-19.5 \% \%_{0} \pm 0.3 \%\right.$ for $\delta^{13} \mathrm{C}$ and $+8.8 \%$ o $\pm 1.0 \%$ o for $\left.\delta^{15} \mathrm{~N}\right)$ and Cârlomăneşti $(-19.3 \%$ o $\pm 0.2 \%$ and $+9.6 \%$ o $\pm 0.4 \%$ o $)$ are statistically significantly different for $\delta^{15} \mathrm{~N}$ (Mann-Whitney $U$ test, $U=447, p=0.001$ ) but not for $\delta^{13} \mathrm{C}$ (Mann-Whitney $U$ test, $U=370, p=0.063$ ), and this is also true when juvenile individuals are excluded. If the youngest individuals (i.e. under 4-year-olds) are excluded, then the differences are statistically significant for both $\delta^{13} \mathrm{C}$ and $\delta^{15} \mathrm{~N}(\mathrm{p}<0.02$ for both variables).

The Sărata Monteoru population is characterised by slightly lower average $\delta^{13} \mathrm{C}$ and noticeably lower $\delta^{15} \mathrm{~N}$ values compared to Cârlomăneşti. These differences are unlikely to be due to variations in local baseline isotope values, since faunal isotope values from the two sites are similar. Figure 3 displays the average values for humans (excluding juveniles) from both sites with 1SD error bars, plotted against mean values for animals from both sites (excluding the above-mentioned outliers in the faunal data set with unusual $\delta^{13} \mathrm{C}$ values).

At Sărata Monteoru, cattle and caprines - the principal livestock species, according to their dominance in Monteoru archaeozoological assemblages (see Becker, 1999, 2000) have average $\delta^{15} \mathrm{~N}$ values $2.3 \%$ lower than humans, while for Cârlomăneşti $\Delta^{15} \mathrm{~N}$ between livestock and human averages is 3.6\% . Given livestock $\delta^{15} \mathrm{~N}$ values are similar between the two sites, the higher human $\delta^{15} \mathrm{~N}$ values for Cârlomăneşti can be explained in several ways:

A. The inhabitants of the earlier site, Cârlomăneşti, regularly consumed more animal protein than the later, Sărata Monteoru, community; 
B. The two populations had diets with similar amounts of animal protein, but the inhabitants of Sărata Monteoru consumed much more animal protein in the form of dairy products, which tend to be slightly depleted in both ${ }^{13} \mathrm{C}$ and ${ }^{15} \mathrm{~N}$ compared to meat from the same animal (Nardoto et al., 2006; Huelsemann et al., 2013);

C. Both communities consumed similar proportions of plant and animal protein but the Cârlomăneşti community grew plant food for human consumption with the aid of intensive manuring;

D. Both communities consumed similar amounts of animal protein, but the inhabitants of Cârlomăneşti had a strong preference for meat from very young (suckling) animals or pork from pigs that were stall fed on food waste containing animal protein and/or protein from crops grown under intensive manuring;

E. Since Cârlomăneşti was much closer to the Buzău River, its inhabitants had greater access to freshwater fish.

Hypotheses D and E lack support from the archaeofaunal data, and so are considered unlikely. Moreover, if pigs were reared on food waste, this is more likely to have occurred at Sărata Monteoru given the comparatively high $\delta^{15} \mathrm{~N}$ values of the pigs from that site (Table 2).

\subsection{Quantitative diet reconstruction}

To further explore intra-site differences, we used the Bayesian statistical program FRUITS (Food Reconstruction Using Transferred Isotopic Signals, beta 2.1.1) (Fernandes et al., 2014) to model the diets of the skeletal populations from Sărata Monteoru and Cârlomăneşti.

Using FRUITS, it is possible to consider more than two food groups, as well as factors such as differences in protein content between food groups. The program calculates probability estimates of the proportions of different foods in diet, given the consumer's stable isotope values and those of the different food groups.

We assumed that Bronze Age diets at Cârlomăneşti and Sărata Monteoru comprised three food groups: animals, cereals and legumes. The population means (excluding juveniles) were used as the consumer values. For animals, the site average for the most commonly utilized domesticated species (cattle and caprines, excluding outliers) was used. In the absence of local plant baseline data, published isotope values of Neolithic crops from Germany, Hungary and Bulgaria (Fraser et al., 2011, 2013; Bogaard et al., 2013; Bogaard, 2015 ) were used as proxies. Based on these published data, cereal values were set as $-24 \%$ o and $+2 \%$, and legume values as $-24 \%$ and $0 \%$, for $\delta^{13} \mathrm{C}$ and $\delta^{15} \mathrm{~N}$, respectively.

Two different scenarios were modelled - unmanured plants with 'typical' $\delta^{15} \mathrm{~N}$ values for cereals and legumes (see above), and manured plants with more elevated values observed in the same plants grown under intensive manuring - to allow for the possibility that regular manuring of crops intended for human consumption may have influenced the human $\delta^{15} \mathrm{~N}$ data. The values for manured plants were set as $+5 \%$ or cereals and $+2 \%$ for legumes, based on data from Bogaard et al. (2013), Fraser et al. $(2011,2013)$, and Bogaard (2015).

Table 3. Base values applied in the FRUITS model: consumer value (site average), the different food groups, and their fractions for each dietary proxy $\left({ }^{13} \mathrm{C},{ }^{15} \mathrm{~N}\right)$ along with their 
associated uncertainty (\%) (set as 1-sigma error for consumers and animals, and \pm 0.5 for values that were not directly measured)

\begin{tabular}{|lcccc|}
\hline & \multicolumn{2}{c}{ Sărata Monteoru } & \multicolumn{2}{c|}{ Cârlomăneşti } \\
& $\boldsymbol{\delta}^{\mathbf{1 3}} \mathbf{C}(\mathbf{\%})$ & $\boldsymbol{\delta}^{\mathbf{1 5}} \mathbf{N}(\mathbf{\%})$ & $\boldsymbol{\delta}^{\mathbf{1 3}} \mathbf{C}(\mathbf{\%})$ & $\boldsymbol{\delta}^{\mathbf{1 5}} \mathbf{N}$ (\%) \\
\hline Consumer & $-19.5 \pm 0.2$ & $8.7 \pm 0.8$ & $-19.4 \pm 0.1$ & $9.8 \pm 0.4$ \\
\hline Food groups & & & & \\
\hline Animal & $-19.7 \pm 0.6$ & $6.4 \pm 0.7$ & $-20.2 \pm 0.4$ & $6.2 \pm 1.0$ \\
Cereal (manured) & $-24 \pm 0.5$ & $5 \pm 0.5$ & $-24 \pm 0.5$ & $5 \pm 0.5$ \\
Cereal (unmanured) & $-24 \pm 0.5$ & $2 \pm 0.5$ & $-24 \pm 0.5$ & $2 \pm 0.5$ \\
Legume (manured) & $-24 \pm 0.5$ & $2 \pm 0.5$ & $-24 \pm 0.5$ & $2 \pm 0.5$ \\
Legume (unmanured) & $-24 \pm 0.5$ & $0 \pm 0.5$ & $-24 \pm 0.5$ & $0 \pm 0.5$ \\
\hline Food values & & & & \\
\hline Animal protein & $-21.7 \pm 0.6$ & $8.4 \pm 0.7$ & $-22.2 \pm 0.4$ & $8.2 \pm 1.0$ \\
Animal energy & $-27.7 \pm 0.6$ & N/A & $-28.2 \pm 0.4$ & N/A \\
Cereal (manured) protein & $-26 \pm 0.5$ & $5 \pm 0.5$ & $-26 \pm 0.5$ & $5 \pm 0.5$ \\
Cereal (manured) energy & $-23.5 \pm 0.5$ & N/A & $-23.5 \pm 0.5$ & N/A \\
Cereal (unmanured) protein & $-26 \pm 0.5$ & $2 \pm 0.5$ & $-26 \pm 0.5$ & $2 \pm 0.5$ \\
Cereal (unmanured) energy & $-23.5 \pm 0.5$ & N/A & $-23.5 \pm 0.5$ & N/A \\
Legume (manured) protein & $-26 \pm 0.5$ & $2 \pm 0.5$ & $-26 \pm 0.5$ & $2 \pm 0.5$ \\
Legume (manured) energy & $-23.5 \pm 0.5$ & N/A & $-23.5 \pm 0.5$ & N/A \\
Legume (unmanured) protein & $-26 \pm 0.5$ & $0 \pm 0.5$ & $-26 \pm 0.5$ & $0 \pm 0.5$ \\
Legume (unmanured) energy & $-23.5 \pm 0.5$ & N/A & $-23.5 \pm 0.5$ & N/A \\
\hline Offsets & $4.8 \pm 0.5$ & $5 \pm 1$ & $4.8 \pm 0.5$ & $5 \pm 1$ \\
\hline
\end{tabular}

The isotopic composition of food group macronutrients was calculated based on previously reported offsets between macronutrient and collagen isotope values, summarized in Fernandes et al. $(2014,2015)$. For terrestrial animal meat, the offsets are $\Delta{ }^{13} \mathrm{C}_{\text {protein-collagen }}=-2 \%, \Delta^{13} \mathrm{C}_{\text {energy-collagen }}=-8 \%$, $\Delta \Delta^{15} \mathrm{~N}_{\text {protein-collagen }}=+2 \%$; for cereal crops and legumes $\Delta^{13} \mathrm{C}_{\text {protein-collagen }}=-2 \%, \Delta^{13} \mathrm{C}_{\text {energy-collagen }}=+0.5 \%$. The diet-to-collagen isotopic offsets for $\delta^{13} \mathrm{C}$ and $\delta^{15} \mathrm{~N}$ were set as $4.8 \pm 0.5 \%$ (Fernandes et al., 2012) and $5 \pm 1 \%$ (Hedges and Reynard, 2007; O'Connell et al., 2012), respectively. The full list of parameter values used for the two sites and for both scenarios is given in Table 3.

Table 4 provides an overview of the estimates generated by FRUITS for the four different scenarios. Scenarios 1 (Sărata Monteoru) and 3 (Cârlomăneşti) take into account the potential manuring effect on both cereals and legumes, reflected in higher plant $\delta^{15} \mathrm{~N}$ values; scenarios 2 (Sărata Monteoru) and 4 (Cârlomăneşti) consider unmanured values for plants. The estimates represent calorie contributions for each food group, the calorie contribution from each food fraction, and the calorie contribution of each food group toward an isotopic proxy (either ${ }^{13} \mathrm{C}$ or ${ }^{15} \mathrm{~N}$ ). The estimates for ${ }^{13} \mathrm{C}$ and ${ }^{15} \mathrm{~N}$ differ due to the former including a routed carbon contribution from energy (i.e. carbohydrates and lipids). The margin of error on individual estimates ranges between $12 \%$ and $25 \%$, which demands caution when interpreting the results. Combining the data for Proxy (Food) (\%) would reduce the errors to between $10 \%$ and $15 \%$ (see Table 4). and Cârlomăneşti populations and for both dietary scenarios. Energy includes both lipids 
and carbohydrates. The estimates represent calorie contributions for each food group (Food [\%]), the calorie contribution from each food fraction (Fraction [\%]), and the calorie contribution of each food group toward an isotopic proxy $\left({ }^{13} \mathrm{C},{ }^{15} \mathrm{~N}\right.$, and the weighted mean of the two) (Proxy [\%])

\begin{tabular}{|c|c|c|c|c|}
\hline & \multicolumn{2}{|c|}{ Sărata Monteoru } & \multicolumn{2}{|c|}{ Cârlomăneşti } \\
\hline & $\begin{array}{l}\text { Scenario } 1 \\
\text { (manured) }\end{array}$ & $\begin{array}{c}\text { Scenario } 2 \\
\text { (unmanured) }\end{array}$ & $\begin{array}{l}\text { Scenario } 3 \\
\text { (manured) }\end{array}$ & $\begin{array}{c}\text { Scenario } 4 \\
\text { (unmanured) }\end{array}$ \\
\hline \multicolumn{5}{|l|}{ Food $(\%)$} \\
\hline Animal & $19 \pm 14$ & $29 \pm 15$ & $27 \pm 18$ & $37 \pm 16$ \\
\hline Cereal & $35 \pm 24$ & $38 \pm 24$ & $41 \pm 25$ & $40 \pm 24$ \\
\hline Legume & $46 \pm 21$ & $33 \pm 19$ & $32 \pm 19$ & $23 \pm 16$ \\
\hline \multicolumn{5}{|l|}{ Fraction (\%) } \\
\hline Protein & $21 \pm 4$ & $21 \pm 4$ & $20 \pm 4$ & $21 \pm 4$ \\
\hline Energy & $79 \pm 4$ & $79 \pm 4$ & $80 \pm 4$ & $79 \pm 4$ \\
\hline \multicolumn{5}{|c|}{ Proxy (Food) (\%) } \\
\hline${ }^{13} \mathrm{C}$ (Animal) & $21 \pm 15$ & $32 \pm 15$ & $30 \pm 18$ & $41 \pm 16$ \\
\hline${ }^{13} \mathrm{C}$ (Cereal) & $31 \pm 23$ & $33 \pm 23$ & $37 \pm 24$ & $35 \pm 23$ \\
\hline${ }^{13} \mathrm{C}$ (Legume) & $48 \pm 21$ & $35 \pm 19$ & $33 \pm 19$ & $24 \pm 16$ \\
\hline${ }^{15} \mathrm{~N}$ (Animal) & $26 \pm 17$ & $40 \pm 16$ & $37 \pm 20$ & $51 \pm 16$ \\
\hline${ }^{15} \mathrm{~N}$ (Cereal) & $20 \pm 18$ & $22 \pm 19$ & $25 \pm 21$ & $22 \pm 18$ \\
\hline${ }^{15} \mathrm{~N}$ (Legume) & $54 \pm 20$ & $38 \pm 19$ & $38 \pm 20$ & $27 \pm 16$ \\
\hline \multicolumn{5}{|c|}{ Combined ${ }^{13} \mathrm{C}+{ }^{15} \mathrm{~N}$} \\
\hline Animal & $23 \pm 11$ & $36 \pm 11$ & $33 \pm 13$ & $46 \pm 11$ \\
\hline Cereal & $24 \pm 14$ & $26 \pm 15$ & $30 \pm 16$ & $27 \pm 14$ \\
\hline Legume & $51 \pm 14$ & $36 \pm 13$ & $35 \pm 14$ & $25 \pm 11$ \\
\hline
\end{tabular}

Despite the large error range, there are apparent differences in the model estimates for both sites depending on whether values for manured or unmanured plants were used. Based on high crop $\delta^{15} \mathrm{~N}$ values, some authors (e.g. Bogaard et al., 2013; Fraser et al., 2013; Vaiglova et al., 2014; Bogaard, 2015) have proposed that manuring was widely practised among Central and Southeast European farmers since the Neolithic. However, Monteoru settlements were often located on fertile black earth (chernozem) soils which tend to maintain their fertility naturally without frequent manuring. While this does not exclude the possibility that low-intensity manuring occurred incidentally, i.e. by animals grazing near the farmlands or on fallow fields, without direct data from associated plant remains it is impossible to determine the real effect (if any) of manuring on Monteoru $\delta^{15} \mathrm{~N}$ values.

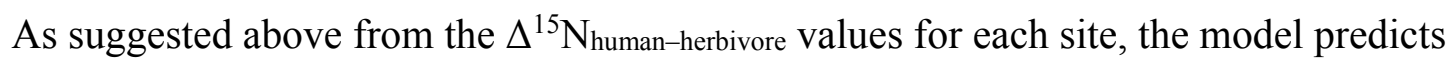
greater reliance on animal products at Cârlomăneşti. Irrespective of whether manured or unmanured scenarios are compared, the contribution of animal-based foods to total calorie intake, total dietary protein and total dietary energy on average are $10-14 \%$ greater for Cârlomăneşti compared to Sărata Monteoru. When lower plant $\delta^{15} \mathrm{~N}$ values, characteristic of unmanured crops, are used the model predicts on average ca. $15 \%$ greater importance in both sites of animal-based protein compared to legume-derived protein.

For both sites, the model predicts that plant foods accounted for most of the calories consumed, and in most scenarios plant protein also accounted for more than half of total protein intake. Estimates for the cereal food group showed the least variability, suggesting 
similar contributions for both sites, irrespective of the presence or absence of a manuring effect on plant $\delta^{15} \mathrm{~N}$ values. Manured values led to greater estimated contributions from legumes to total calorie intake, with scenario 1 (Sărata Monteoru, manured plants) displaying the highest contribution of legumes to both total calorie intake (ca. $46 \%$ ) and to dietary protein (ca. 54\%). Even at Cârlomăneşti, for which the model predicts a lower contribution from legumes, they are still estimated to account for at least a quarter of total calorie intake, and to contribute significantly to dietary protein.

Based on archaeobotanical evidence from Southeast Europe from the Neolithic onwards, the protein-rich legumes were grown on a consistent basis throughout the region, although they are usually reported in smaller numbers compared to remains of wheat and barley (e.g. Gyulai, 1993; Cârciumaru, 1996; Monah, 2007; Reed, 2013). According to Bonsall et al. (2007), ethnohistorical sources suggest that a typical peasant farming society in Southeast Europe commonly received most of their sustenance from cultivated plants such as cereals, legumes and fruits, with only a modest contribution from dairy products (meat was regarded as luxury). This is in accordance with the model's predictions for the two Monteoru sites.

While the modelled estimates have large associated uncertainties, the results nevertheless suggest differences in the way dietary resources were utilized between the two sites, and possibly, also between the Early and Late Monteoru periods. The most likely interpretation of the available data involves a modest decrease at later-period Sărata Monteoru in dependence on animal-derived products and a greater reliance on plant carbohydrates for energy, with legumes increasing in importance as a source of dietary protein over animal protein. This trend seems consistent when comparing scenarios 1 and 3 (both sites, manured plants), 2 and 4 (both sites, unmanured plants), 1 and 4 (Sărata Monteoru manured, Cârlomăneşti unmanured), but does not hold in comparisons between scenarios 2 and 3 (Sărata Monteoru unmanured, Cârlomăneşti manured).

Given the similarities of the palaeoecological and archaeological material recovered from each site, a significant change in economic activities is an unlikely explanation for the observed differences. While no clear trend can be discerned between Early and Middle Bronze Age faunal assemblages from the Monteoru culture area, available archaeozoological evidence for the Eneolithic and Bronze Age Carpathians does indicate a shift from caprine to cattle husbandry during the Bronze Age, with cattle becoming the dominant species by the Late Bronze Age (Becker, 1999, 2000). The rise in the importance of cattle husbandry during the Carpathian Bronze Age may have increased the amount of milk available for dairy products; alternatively, a rise in the popularity of, or developments, in dairying may have led to the preferential keeping of cows. The maturity of cattle in several middle Danube sites during the second millennium BC has also been taken to imply an important role for dairy cows (Barker, 1989). Additionally, as animals kept for dairying would be slaughtered less often than those kept for meat, it would presumably reduce the amount of (cattle) meat consumed - and the calories obtained from animal products. It is thus possible that a change in dietary practices between the Early and Late Monteoru periods as represented by the two sites included in this study may have involved a shift from a more meat-based economy to a more dairy- and plant-based economy. 


\section{Conclusions}

Acknowledgments: The research was supported by the NERC Isotope Geosciences Facilities

548 Steering Committee (grant number IP-1611-0516), and the Kristjan Jaak Scholarship

549 programme (funded and managed by the Archimedes Foundation in collaboration with the

550 Ministry of Education and Research in Estonia; grant number 16-4.2/853). We thank Prof.

551 Gordon Cook and an anonymous reviewer for constructive comments and suggestions that

552 have improved the text, and Alan Dalton and Dr Catriona Pickard for assistance with

553 collagen pretreatment. 
556 Ambrose, S. H., 1990. Preparation and characterization of bone and tooth collagen for isotopic analysis. J. Arch. Sci. 17, 431-451.

Ambrose, S. H., DeNiro, M. J., 1986. The isotopic ecology of East African mammals.

560 Barker, G., 1989. Prehistoric farming in Europe. Cambridge University Press.

561

562

563

564

565

566

567

568

569

570

571

572

573

574

575

576

577

578

579

580

581

582

583

584

585

586

587

588

589

590

591

592

Bartosiewicz, L., 2013. Animals in Bronze Age Europe, in: Fokkens, H., Harding, A. (Eds), The Oxford Handbook of the European Bronze Age. Oxford University Press, Oxford, pp. 328-347.

Bârzu, L., 1989. La station de Sărata-Monteoru: La nécropole $n^{\circ} 4$ de l'époque de bronze. Dacia N.S. 33, 39-78.

Becker, C., 1999. Domesticated and wild animals as evidenced in the Eneolithic-Bronze Age cultures Coțofeni and Monteoru, Romania, in: Benecke, N. (Ed.), The Holocene history of the European Vertebrate Fauna: Modern aspects of research, workshop held 6-9th April 1998 in Berlin, Archäologie in Eurasien 6. Rahden/Westf., Leidorf, pp. 91-105.

Becker, C., 2000. Subsistenzstrategien während der frühen Metallzeit im zentralkarpatischen Raum - neue archäozoologische Daten zur Coțofeni- und Monteoru-Kultur. Praehistorische Zeitschrift. 75(1), 63-92.

Bocherens, H., Drucker, D., 2003. Trophic level isotopic enrichment of carbon and nitrogen in bone collagen: case studies from recent and ancient terrestrial ecosystems. Int. J. Osteoarchaeol. 13, 46-53.

Bogaard, A., 2015. New insights into early farming practice and diet from stable isotope analysis of crop assemblages, in: Brink, K., Hydén, S., Jennbert, K., Larsson, L., Olausson, D. (Eds), Neolithic diversities: perspectives from a conference in Lund, Sweden. Acta Archaeologica Lundensia, 8(65), pp. 33-42.

Bogaard, A., Fraser, R., Heaton, T. H. E., Wallace, M., Vaiglova, P., Charles, M., Jones, G., Evershed, R. P., Styring, A. K., Andersen, N. H., Arbogast, R.-M., Bartosiewicz, L., Gardeisen, A., Kanstrup, M., Maier, U., Marinova, E., Ninov, L., Schäfer, M., Stephan, E., 2013. Crop manuring and intensive land management by Europe's first farmers. PNAS. 110(31), 12589-12594.

Bökönyi, S., 1972. The vertebrate fauna, in: Srejović, D. (Ed.), Europe's First Monumental Sculpture. New Discoveries at Lepenski Vir. Stein and Day, pp. 186-189.

Bonsall, C., Lennon, R., McSweeney, K., Stewart, C., Harkness, D., Boroneanţ, V., Bartosiewicz, L., Payton, R., Chapman, J., 1997. Mesolithic and Early Neolithic in the Iron Gates: a palaeodietary perspective. Journal of European Archaeology. 5(1), 50-92.

Bonsall, C., Cook, G., Hedges, R., Higham, T., Pickard, C., Radovan, I., 2004. Radiocarbon and stable isotope evidence of dietary change from the Mesolithic to the Middle Ages in the Iron Gates: new results from Lepenski Vir. Radiocarbon. 46(1), 293-300. 
593 Bonsall, C., Horvat, M., McSweeney, K., Masson, M., Higham, T. F., Pickard, C., Cook, G.

594 T., 2007. Chronological and dietary aspects of the human burials from Ajdovska Cave,

595 Slovenia. Radiocarbon. 49(2), 727-740.

596 Borić, D., Grupe, G., Peters, J., Mikić, Ž., 2004. Is the Mesolithic-Neolithic subsistence 597 dichotomy real? New stable isotope evidence from the Danube Gorges. European Journal of 598 Archaeology. 7(3), 221-248.

599 Cârciumaru, M., 1983. Consideraţii paleobotanice şi contribuţii la agricultura geto-dacilor.

600 Thraco-Dacica. 4, 126-134.

601 Cârciumaru, M., 1996. Paleoetnobotanica. Iaşi.

602 Cook, G.T., Bonsall, C., Hedges, R. E., McSweeney, K., Boroneanţ, V., Pettitt, P. B., 2001. 603 A freshwater diet-derived ${ }^{14} \mathrm{C}$ reservoir effect at the Stone Age sites in the Iron Gates Gorge. 604 Radiocarbon. 43(2A), 453-460.

605 Fernandes, R., Nadeau, M.- J., Grootes, P. M., 2012. Macronutrient-based model for dietary 606 carbon routing in bone collagen and bioapatite. Archaeol. Anthrop. Sci. 4(4), 291-301.

607 Fernandes, R., Millard A. R., Brabec, M., Nadeau, M.-J., Grootes, P., 2014. Food 608 Reconstruction Using Isotopic Transferred Signals (FRUITS): a Bayesian model for diet 609 reconstruction. PLoS ONE. 9(2), e87436.

610 Fernandes, R., Grootes, P., Nadeau, M.-J., Nehlich, O., 2015. Quantitative diet reconstruction 611 of a Neolithic population using a Bayesian mixing model (FRUITS): the case study of Ostorf 612 (Germany). Am. J. Phys. Anthropol. 158(2), 325-340.

613 Fraser, R. A., Bogaard, A., Heaton, T., Charles, M., Jones, G., Christensen, B. T., Halstead, 614 P., Merbach, I., Poulton, P. R., Sparkes, D., Styring, A. K., 2011. Manuring and stable 615 isotope ratios in cereals and pulses: towards a new archaeobotanical approach to the inference 616 of land use and dietary practices. J. Archaeol. Sci. 38, 2790-2804.

617 Fraser, R. A., Bogaard, A., Schäfer, M., Arbogast, R., Heaton, T. H., 2013. Integrating 618 botanical, faunal and human stable carbon and nitrogen isotope values to reconstruct land use 619 and palaeodiet at LBK Vaihingen an der Enz, Baden-Württemberg. World Archaeology. $620 \quad 45(3), 492-517$.

621 Fuller, B. T., Fuller. J. L., Sage, N. E., Harris, D. A., O’Connell, T. C., Hedges, R. E. M., 622 2004. Nitrogen balance and $\delta^{15} \mathrm{~N}$ : Why you're not what you eat during pregnancy. Rapid 623 Communications in Mass Spectrometry. 18, 2889-2896.

624 Fuller, B. T., Fuller, J. L., Harris, D. A., Hedges, R.E.M., 2006. Detection of breastfeeding 625 and weaning in modern human infants with carbon and nitrogen stable isotope ratios. Am. J. 626 Phys. Anthropol. 129, 279-293.

627 Fuller, B. T., Müldner, G., Van Neer, W., Ervynck, A., Richards, M. P., 2012. Carbon and 628 nitrogen stable isotope ratio analysis of freshwater, brackish and marine fish from Belgian 629 archaeological sites (1st and 2nd millennium AD). J. Anal. At. Spectrom. 27, 807-820.

630 Gyulai, F., 1993. Environment and agriculture in Bronze Age Hungary. Archaeolingua, 4, 631 Budapest.

632 Harding, A. F. 2000. European societies in the Bronze Age. Cambridge University Press, 633 Cambridge. 
636 Huelsemann, F., Koehler, K., Braun, H., Schaenzer, W., Flenker, U., 2013. Human dietary $637 \delta^{15} \mathrm{~N}$ intake: representative data for principle food items. Am. J. Phys. Anthropol. 152, 58-66.

638 Katzenberg, M. A., Lovell, N. C., 1999. Stable isotope variation in pathological bone. Int. J. 639 Osteoarchaeol. 9, 316-324.

640 Lightfoot, E., Šlaus, M., O'Connell, T. C., 2012. Changing cultures, changing cuisines: 641 cultural transitions and dietary change in Iron Age, Roman, and Early Medieval Croatia. Am. 642 J. Phys. Anthropol. 148(4), 543-556.

643 Lightfoot, E., Šlaus, M., Šikanjić, P. R., O’Connell, T. C., 2015. Metals and millets: Bronze 644 and Iron Age diet in inland and coastal Croatia seen through stable isotope analysis. 645 Archaeol. Anthropol. Sci. 7(3), 375-386.

646 Maximilian, C., 1962. Sărata-Monteoru. Studiu Antropologic. Academia Republicii Populare 647 Romîne.

648 Monah, F., 2007. The spread of cultivated plants in the region between the Carpathians and 649 Dniester, $6^{\text {th }}-4^{\text {th }}$ millennia cal BC, in: Colledge, S., Conolly, J. (Eds.), The Origins and 650 Spread of Domestic Plants in Southwest Asia and Europe. University College, London, 651 Institute of Archaeology, pp. 111-123.

652

Motuzaite-Matuzeviciute, G., Staff, R. A., Hunt, H. V., Liu, X., Jones, M. K., 2013. The early chronology of broomcorn millet (Panicum miliaceum) in Europe. Antiquity. 87(338), 10736541085.

655 Motzoi-Chicideanu, I., 1995. Fremdgüter im Monteoru-Kulturraum, in: Hänsel, B. (Ed.), 656 Handel, Tausch und Verkehr im bronze- und eisenzeitlichen Südosteuropa, Südosteuropa657 Schr. 17, Prähistorische Archäologie in Südosteuropa 11. Berlin, pp. 219-242.

Motzoi-Chicideanu, I., 2011. Obiceiuri funerare in epoca bronzului la Dunărea Mijlocie şi 659 Inferioară. Editura Academiei Române, București.

660 Motzoi-Chicideanu, I., Chicideanu-Şandor, M., 2015. Câteva date noi privind cronologia 661 culturii Monteoru. Mousaios. 20, 9-53.

662 Motzoi-Chicideanu et al. 2012a = Motzoi-Chicideanu, I., Chicideanu-Şandor, M., 663 Constantinescu, M., 2012. Observatii prelimina reprivind cercetările efectuate în anii 2008664 2009, 2011-2012 la cimitirul din epoca bronzului de la Cârlomănesti. Mousaios. 17, 47-61.

665 Motzoi-Chicideanu et al. 2012b = Motzoi-Chicideanu, I., Matei, S., Gugiu, D., 2012. O piesă 666 de harnaşament din epoca bronzului descoperită la Cârlomăneşti-Cetăţuia. Mousaios. 17, 6566795.

668 Murray, M. L., Schoeninger, M. J., 1988. Diet, status, and complex social structure in Iron 669 Age Central Europe: some contributions of bone chemistry, in: Tribe and Polity in Late 670 Prehistoric Europe. Springer, US, pp. 155-176.

671 Nardoto, G. B., Silva, S., Kendall, C., Ehleringer, J. R., Chesson, L. A., Ferraz, E. S. B., 672 Moreira, M. Z., Ometto, J. P. H. B., Martinelli, L. A., 2006. Geographical patterns of human 673 diet derived from stable-isotope analysis of fingernails. Am. J. Phys. Anthropol. 131, 137674146. 

freshwater fish consumption: a case study from the Danube Gorges, SE Europe. J. Archaeol.

677 Sci. 37(5), 1131-1139.

678 Nestor, I., 1933. Der Stand der Vorgeschichtsforschung in Rumänien, 22, Bericht der 679 Römisch-Germanischen Kommission.

680 Nitsch, E. K., Humphrey, L. T., Hedges, R. E. M., 2011. Using stable isotope analysis to 681 examine the effect of economic change on breastfeeding practices in Spitalfields, London, 682 UK. Am. J. Phys. Anthropol. 146, 619-628.

683 O’Connell, T. C., Hedges, R. E. M., 1999. Investigations into the effect of diet on modern 684 human hair isotope values. Am. J. Phys. Anthropol. 108, 409-425.

685 O’Connell, T. C., Hedges, R. E. M., Healey, M. A., Simpson, A. H. R. W., 2001. Isotopic 686 comparison of hair, nail and bone: modern analyses. J. Archaeol. Sci. 28, 1247-1255.

687 O’Connell, T. C., Kneale, C. J., Tasevska, N., Kuhnle, G. G. C., 2012. The diet-body offset in 688 human nitrogen isotopic values: a controlled dietary study. Am. J. Phys. Anthropol. 149, $689426-434$.

690 Petroutsa, E. I., Manolis, S. K., 2010. Reconstructing Late Bronze Age diet in mainland 691 Greece using stable isotope analysis. J. Archaeol. Sci. 37, 614-620.

692 Petzke, K. J., Boeing, H., Metges, C. C., 2005. Choice of dietary protein of vegetarians and 693 omnivores is reflected in their hair protein ${ }^{13} \mathrm{C}$ and ${ }^{15} \mathrm{~N}$ abundance. Rapid Communications in 694 Mass Spectrometry. 19, 1392-1400.

695 Reed, K. A., 2013. Farmers in transition: the archaeobotanical analysis of the Carpathian 696 Basin from the Late Neolithic to the Late Bronze Age (5000-900 BC). Unpublished PhD 697 dissertation, University of Leicester.

698 Richards, M. P., Mays, S., Fuller, B. T., 2002. Stable carbon and nitrogen isotope values of 699 bone and teeth reflect weaning age at the medieval Wharram Percy site, Yorkshire, UK. Am.

700 J. Phys. Anthropol. 119, 205-210.

701 Schoeninger, M. J., DeNiro, M. J., 1984. Nitrogen and carbon isotopic composition 702 of bone collagen from marine and terrestrial animals. Geochimica et Cosmochimica 703 Acta. 48, 625-639.

704 Sealy, J. C., 2001. Body tissue chemistry and palaeodiet, in: Brothwell, D. R., Pollard, A. M. 705 (Eds.), Handbook of Archaeological Sciences. Wiley, pp. 269-279.

706 Stika, H.-P., Heiss, A. G., 2013. Plant cultivation in the Bronze Age, in: Fokkens, H., 707 Harding, A. (Eds), The Oxford Handbook of the European Bronze Age. Oxford University 708 Press, Oxford, pp. 348-369.

709 Szpak, P., 2014. Complexities of nitrogen isotope biogeochemistry in plant-soil systems:

710 implications for the study of ancient agricultural and animal management practices. Frontiers 711 in Plant Science 5.

712 Triantaphyllou, S., Richards, M. P., Zerner, C., Voutsaki, S., 2008. Isotopic dietary 713 reconstruction of humans from Middle Bronze age Lerna, Argolid, Greece. J. Archaeol. Sci. $71435(11), 3028-3034$. 
715 Tsutaya, T., Yoneda, M., 2013. Quantitative reconstruction of weaning ages in archaeological 716 human populations using bone collagen nitrogen isotope ratios and approximate Bayesian 717 computation. PLoS ONE. 8(8), e72327.

718 Vaiglova, P., Bogaard, A., Collins, M., Cavanagh, W., Mee, C., Renard, J., Lamb, A., 719 Gardeisen, A., Fraser, R., 2014. An integrated stable isotope study of plants and animals from 720 Kouphovouno, southern Greece: a new look at Neolithic farming. J. Archaeol. Sci. 42, 201721215.

722 van Klinken, G. J., 1999. Bone collagen quality indicators for palaeodietary and radiocarbon 723 measurements. J. Archaeol. Sci. 26, 687-695.

724 Vika, E., 2011. Diachronic dietary reconstructions in ancient Thebes, Greece: results from 725 stable isotope analyses. J. Archaeol. Sci. 38(5), 1157-1163.

726 Vulpe, A., 1995. Epoca bronzului în spaţiul carpato-dunărean, privire general, in: Petrescu 727 Dâmboviţa, M. (Ed.), Comori ale epocii bronzului în România. Bucureşti, pp. 17-23..

728 Waters-Rist, A. L., Katzenberg, M. A., 2010. The effect of growth on stable nitrogen isotope

729 ratios in subadult bone collagen. Int. J. Osteoarchaeol. 20, 172-191. 